Cooperative Control System of Human and Robot Based on Speech and Camera Image OTamano.Y (Saga Univ.), Watanabe.K (Saga Univ.), Izumi.K (Saga Univ.), Nose.Y (Saga Univ.)

本稿では，音声と画像の使用によるヒトとロボットの協調制御システムを提案する，提案手法において，音声はヒトからロボッ トへの指令, 画像はヒトがロボットの作業状況を確認するために利用する。本手法の利点としては, ヒトは画像情報が得られるの で，作業の指示にカラー情報や形状などを使ってロボットに指示できるので，比較的容易に所望の作業を指示できることが挙げら れる，本手法を 7 自由度マニピュレータの手先を指示色に移動させる簡単な実験に適用し，その有効性を検討寸る。

\title{
2P1-H-17 Behavior Adaptation of Robotic Lamp
}

Sato.T (Tokyo univ.), OHosseinbor.M (Tokyo univ.), Kuroiwa.T (Tokyo univ.), Fukui.R (Tokyo univ.), Tamura.J (Tokyo univ.), Mori.T (Tokyo univ.)

Based on the concept of "behavior and personal adaptation" this paper proposes a system which assists its user by illuminating the desired area in the preferable way depending on user's behavior and identity. This system utilizes robotic lamp not only as illumination tool but also as an input device. Posture and brightness of robotic lamp can be controlled via network and user can adjust robotic lamp's posture and brightness by physical contact to the lamp. In other words, user can change robotic lamp's posture by pushing on the joints and can change the brightness using a rotary encoder installed on robotic lamp's base. User teaches his desire posture and brightness for each behavior by physical contact. The system would take the learned posture and brightness from next time the corresponding behavior takes place. The system consists of the following three main modules:1) Behavior recognition module: A high resolution pressure sensor distributed floor is utilized to recognize predefined behaviors of a) Entering the room b) Sitting on the chair c) Sitting on the cushion d) Being on bed and e) Getting up from bed.The sensing floor can detect whether user is sitting on objects such as chair and cushion. This module also detects user's physical contact to robotic lamp which may mean a command (ex. Turn off) or may be to adjust the illumination way.2) Support decider module: This module decides robotic lamp's posture and brightness based on behavior recognition results. Support decider module has a data base which includes the desired posture and brightness of the robotic lamp for each behavior of every user. The data base would be updated, in case a new way of illumination is taught to the system. 3 ) Robotic lamp controllerExperiments showed predefined behavior mentioned above can be recognized with almost 100 $\%$ precision. The results also showed that the support decider module's judgments were correct for these behaviors. Finally five people took part in the experiment and taught their desired way of illumination for each behavior. It was confirmed by each user that the illumination way and brightness is what was taught. The adaptation process for the robotic lamp is proved to realize an automatic system that illuminates various areas depending on user's behavior.

2P1-H-18 RoBE を用いたモバイルマニピュレータの実時間自己衝突回避制御

一第 3 報人間とのインタラクションを考慮した自己衝突回避一

○瀬戸 文美 (東北大), 小菅一弘 (東北大), 平田 泰久 (東北大)

Real-time Control of Self-collision Avoidance for Mobile Manipulator using RoBE

- Self-collision Avoidance considering Interaction with Human -

OSeto.F (Tohoku univ.), Kosuge.K (Tohoku univ.), Hirata.Y (Tohoku univ. PRESTO JST)

本研究では人間と協調して作業を行うロボットに㧍ける実時間での自己衝突回避手法を実現することを目的とし，これまで口 ボット形状の弹性要素表現” RoBE(Representation of Body by Elastic elements)”とRoBE を用いた実時間自己衝突回避制 御を提案してきた．本稿では力情報に基づくロボットと人間との協調作業中においても自己衝突回避を可能とする，RoBEにより 発生寸る反力に基づく自己衝突回避の制御手法を提案する。提案する手法を人間協調型双腕移動ロボット” MR Helper”に適用 し，人間からの操作力に基づいてロボットが動作する場合の自己衝突回避実験を行い，提案する手法の有効性を確認する.

2P1-H-35 対人相互作用ロボットのための視覚機能と運動機能との計算機網を介した連携

山口 直哉 (東理大), 図師 洋三 (東理大), ○菊池 隆司 (東理大), 溝口 博 (東理大)

Network based cooperation of vision and mobility for Human-Robot interaction

Yamaguchi.N (TUS), Zushi.Y (TUS), OKikuchi.T (TUS), Mizoguchi.H (TUS)

近年，人間とロボットが交流する機会が増えているおり，著者らは人と相互にやり取りのできるエンターテイメント性のあるロ ボットの実現を目指す。本研究ではその実現のため，人とボール遊びのできる対人相互作用ロボットを想定し，それに必要な視覚・ 運動機能の開発と, その連携を行った。必要な機能は, 顔発見, 及びボール遊びをしている人を認識するための顔認識, さらに, ボールの発見，ボールの追跡である．顔発見は相関演算に基づくテンプレートマッチングを用いた顔発見システムを用いる．この 手法による顔発見は，複雑背景下でも発見が可能である，そしてこの顔発見システムに逐次型線形判別分析を組み合わせることに よって, 顔認識システムを構成した。これにより，人の判別が可能となった。ボール発見は，上記の顔発見システムを改良しカメ ラの入力画像内から任意の場所をテンプレートとして切り出すことによって, 様々な模様や色のボールでも発見する手法をとった. ロボカップ等に用いられている色抽出による発見と異なり，周囲の色に左右されず発見することが可能である。これらの発見され た対象をカメラのパン・チルト機能を用いて追跡し，人やボールが動き回る中でも対象を常に画像内に捕らえることが可能となっ た．カメラ追跡時のパン角度によって，カメラと発見対象物の角度が取得できる。この視覚情報を元にした動作を行う移動口ボッ 卜を作成し, 移動ロボットによるボール追跡を可能とした. 